\title{
Interventions to increase adherence to acne treatment
}

\author{
This article was published in the following Dove Press journal: \\ Patient Preference and Adherence \\ II October 2016 \\ Number of times this article has been viewed
}

\author{
Sara Moradi Tuchayi' \\ Tiffany M Alexander ${ }^{2}$ \\ Anish Nadkarni' \\ Steven R Feldman 1,3,4 \\ 'Center for Dermatology Research, \\ Department of Dermatology, Wake \\ Forest University School of \\ Medicine, Winston-Salem, NC, \\ ${ }^{2}$ Howard University College \\ of Medicine, Washington, DC, \\ ${ }^{3}$ Department of Public Health \\ Sciences, ${ }^{4}$ Department of Pathology, \\ Wake Forest University School of \\ Medicine, Winston-Salem, NC, USA
}

Correspondence: Sara Moradi Tuchayi Department of Dermatology, Wake Forest University School of Medicine, 4618 Country Club Road, Winston-Salem, NC 27104, USA

$\mathrm{Tel}+\mathrm{I} 336716$ I763

Fax +I 3367167732

Email samo_1985@yahoo.com
Background: Adherence to acne medication is poor and is a major reason why treatment plans are ineffective. Recognizing solutions to nonadherence is critical.

Objective: The purpose of this study is to describe the hurdles associated with acne nonadherence and to provide mechanisms on how to ameliorate them.

Methods: PubMed database was searched. Of the 419 search results, 29 articles were reviewed to identify hurdles to adherence and corresponding solutions.

Results: Hurdles to primary nonadherence where the medication is not even started, include lack of knowledge, confusion about usage, weak physician-patient relationship, fear of adverse reactions, and cost. Secondary nonadherence hurdles where the medication is started but is not taken as directed include lack of results, complex regimens, side effects, busy lifestyle, forgetfulness, inconvenience, and psychiatric comorbidity. Solutions to these hurdles include treatment simplification, technology, and dynamic education.

Limitations: Adherence is affected by numerous factors, but available literature analyzing acne adherence and interventions to improve adherence to treatment is limited.

Conclusion: There are several hurdles in adhering to acne treatment. Recognition of these hurdles and finding appropriate solutions may be as important to treatment outcomes as choosing the right medication to prescribe.

Keywords: acne vulgaris, adherence, pathogenesis, treatment, quality of life, prevalence, physician-patient relationship, lifestyle, clinic visit, disease severity

\section{Introduction}

Acne vulgaris is a common chronic inflammatory disease that affects 45 million people in the USA. ${ }^{1}$ Acne negatively affects the quality of life - as measured by low self-esteem, increased social and emotional anxiety ${ }^{2,3}$ - and imposes a considerable financial toll. ${ }^{4}$ Annually, US consumers spend $\$ 1.2$ billion on acne medications, ${ }^{1} \$ 233$ per patient on prescribed acne treatments. ${ }^{4}$ The use of more than one medication due to multifactorial pathogenesis of the disease adds cost and complexity to the burden.

One of the factors negatively impacting acne treatment outcomes is poor adherence. Poor adherence is a problem in all medical disciplines, with the average adherence being only $50 \%-60 \%$. ${ }^{5,6}$ Adherence to simple acne regimens is poor; adherence rates for complex regimens are worse. The purpose of this study is to describe the hurdles associated with adherence to acne treatment and to provide mechanisms on how to ameliorate them.

\section{Methods}

The PubMed literature database was searched with the goal of finding hurdles to acne treatment adherence. In PubMed, the search ("acne vulgaris" [all fields] OR 
"acne medication adherence" [all fields]) was performed in July 2015. Limitations consisted of the English language, humans, and publication dates of January 1, 1990 through July 1, 2015. In addition, the reference lists of these articles were searched. The titles, abstracts, and articles were analyzed and the following inclusion criteria were used:

Inclusion criteria:

1. Involvement of patients with acne

2. Studies examining acne treatments

3. Assessing adherence to acne treatments

The keyword search resulted in a total of 419 articles. Through an independent review, 29 articles were selected and used to generate a list of hurdles and interventions for acne medication nonadherence. The hurdles were identified as either primary or secondary medication nonadherence hurdles. Primary nonadherence was defined as "not obtaining or initiating a prescribed medication." Secondary nonadherence refers to a "lack of sufficient treatment usage or early discontinuation of treatment." Interventions identified within the articles were categorized as corresponding solutions to the aforementioned primary or secondary nonadherence hurdles.

\section{Results}

Hurdles to acne treatment adherence can be classified into primary and secondary. Primary adherence hurdles include lack of knowledge about acne condition, confusion about how to use treatment, weak physician-patient relationship, fear of side effects, and costs (Table 1). Secondary adherence hurdles include lack of efficacy, complicated regimens, adverse reactions, lifestyle factors, and psychiatric comorbidity. Solutions to address these hurdles lie in simplification, technology, and dynamic education (Table 2). ${ }^{8-10}$

Findings of literature search with hurdles to acne treatment adherence and interventions are shown in Table 3.

Table I Hurdles to acne treatment adherence

\begin{tabular}{ll}
\hline Primary nonadherence hurdles & $\begin{array}{l}\text { Secondary nonadherence } \\
\text { hurdles* }\end{array}$ \\
\hline $\begin{array}{l}\text { Little knowledge about severity of acne } \\
\text { Weak physician-patient relationship }\end{array}$ & $\begin{array}{l}\text { Lack of acne improvement } \\
\text { Regimen too complex }\end{array}$ \\
$\begin{array}{l}\text { Influence from media or other } \\
\text { physicians }\end{array}$ & Adverse reaction \\
$\begin{array}{l}\text { Already in possession of similar } \\
\text { treatments }\end{array}$ & Difficulty delaying satisfaction \\
$\begin{array}{l}\text { Fear of adverse reaction } \\
\text { High QOL score }\end{array}$ & $\begin{array}{l}\text { Busy lifestyle } \\
\text { Confusion about how to use treatment }\end{array}$ \\
Cost & $\begin{array}{l}\text { Forgetfulness } \\
\text { Inconvenient }\end{array}$ \\
\hline
\end{tabular}

Notes: *Some hurdles likely apply to both primary and secondary adherence. Abbreviation: QOL, quality of life.

\section{Discussion}

Considering the huge burden of acne and low rates of adherence associated with acne medication, more attention to increasing adherence is needed. ${ }^{11,12}$ A variety of hurdles to adherence exist, stemming from both inside and outside the doctor's office. Understanding these hurdles may help dermatologists in creating effective solutions for their patients.

Primary nonadherence is when a patient never even begins taking the medication. The existence of primary nonadherence highlights the need for a strong patient-physician relationship. In a weak relationship, a patient may be more likely to disagree with the dermatologist's recommendations due to information obtained from nonmedical professionals, websites, television advertisements, commercials, and magazine articles. ${ }^{13}$ Other reasons also exist for primary nonadherence. Patients may be indifferent to filling their prescribed medication or begin using it due to a lack of motivation. They may already possess similar treatments or acne may not be bothersome enough for its treatment to be high on their list of priorities. There is also the possibility that the skin condition may improve before even obtaining their prescriptions, negating a need for primary adherence..$^{13,14}$

Secondary nonadherence is when the medication is not taken as prescribed. This type of nonadherence tends to be more prevalent in patients with chronic acne than in those with acute conditions. ${ }^{13}$ One common reason for secondary nonadherence in acne treatment would be side effects. Topical retinoids, which are a first-line therapy, can cause burning, irritation, and dryness. ${ }^{13,15}$ Topical and oral antibiotics used as monotherapy can lead to antibiotic resistance. ${ }^{15}$ Isotretinoin, which is used to treat moderateto-severe acne has been known to be teratogenic and can contribute to cheilitis, dermatitis, arthralgia, increased liver enzymes, cholesterol levels, depression, and even attempted suicide..$^{3,16-18}$ These large numbers of potential adverse events can scare patients from even starting the medication. They may also reduce patients' use and if they occur, may cause patients to discontinue treatment altogether. Another reason for secondary nonadherence is poor efficacy. Many acne medication regimens take many weeks or months for improvement, leading patients into believing that the medication is not working, which leads to lower adherence. ${ }^{19}$ This may be especially true of the patient population suffering from acne, as difficulty "delaying satisfaction" is commonly seen in adolescents. ${ }^{20}$ Complex regimens may also lead to less adherence. One study has shown that going from a single treatment to multiple treatments leads to less adherence. ${ }^{7}$ Other patients may have confusion about treatment usage and 
Table 2 Interventions to acne treatment hurdles

\begin{tabular}{|c|c|c|}
\hline Intervention type & Interventions to primary nonadherence hurdles & Interventions to secondary nonadherence hurdles \\
\hline Simplification & $\begin{array}{l}\text { Consider postponing therapy if patient is content and has } \\
\text { little psychological distress and nonscarring acne }\end{array}$ & $\begin{array}{l}\text { Simplify regimen by using combination therapies and } \\
\text { allowing patients to choose their vehicle } \\
\text { Ask patients to incorporate use of their medication into } \\
\text { their daily activities } \\
\text { Ask patients to place their medications within daily eyesight }\end{array}$ \\
\hline Technology & Electronic transmission of prescription to pharmacy & $\begin{array}{l}\text { Automated text messaging } \\
\text { Follow-up phone calls } \\
\text { Follow-up with internet-based surveys } \\
\text { Recommend phone applications }\end{array}$ \\
\hline Dynamic education & $\begin{array}{l}\text { Verbally and visually educate the patient about their condition } \\
\text { Discuss treatment options with the other physicians } \\
\text { Debunk myths by proactively educating the patients about } \\
\text { side effects } \\
\text { Instruct the patient by giving a demonstration } \\
\text { Use open-ended questions and avoid nonjudgmental and } \\
\text { accusatory remarks } \\
\text { Understanding the pervasive nature of the media and its } \\
\text { influence on patients. Debunk myths and educate patients } \\
\text { about their condition and any anticipated side effects } \\
\text { Ask about previously prescribed treatments and satisfaction } \\
\text { with them } \\
\text { Demonstrate medication use } \\
\text { Know which insurance covers what medications }\end{array}$ & $\begin{array}{l}\text { Determine if the patient is using medication correctly. If } \\
\text { not, educate the patient again. If therapy is truly ineffective } \\
\text { and there is no improvement, abandon treatment and } \\
\text { consider alternatives } \\
\text { Proactively deal with anticipated side effects } \\
\text { Use adjunctive medications, consider comedone extraction } \\
\text { and drainage of cysts } \\
\text { Simplify the regimen by using combination medication, } \\
\text { allow patients to choose their vehicle, and ask patients to } \\
\text { incorporate use of medication into their daily activities } \\
\text { Consider psychiatric consultancy, psychotherapy, or setting } \\
\text { up acne vulgaris support groups }\end{array}$ \\
\hline
\end{tabular}

be discouraged to use the medication. ${ }^{21}$ Lifestyle must also be considered when thinking about reasons for poor adherence. A patient with a busy lifestyle may simply forget to apply it, especially if other reasons for nonadherence exist. Additionally, tumultuous lifestyles or depressive emotional states may contribute to lower psychiatric comorbidities and decreased adherence..$^{22}$

Simplification serves as one solution to nonadherence, as it allows treatment to better fit into a patient's lifestyle. Among patients who were prescribed one, two, or three acne treatments, primary adherence was significantly higher in the patients who were prescribed one medication. ${ }^{7}$ Simplifying the medication vehicle may increase adherence as well. Acne subjects preferred the pump over a tube for dispensing fixed-dose combination of adapalene $0.1 \%$-benzoyl peroxide $2.5 \%$ gel because the pump made it easy to follow their doctor's instructions and apply a consistent amount each time. ${ }^{21}$ Fixed-dose combinations such as a combination of retinoids and antimicrobials simplify the acne therapeutic regimen and increase adherence; this combination simultaneously combats the proliferation of follicular keratinization, Propionibacterium acnes colonization, and release of inflammatory mediators. ${ }^{15}$ However, combination treatments have overcome all adherence obstacles, especially in maintaining good adherence over time. A pilot randomized controlled trial found that even after product demonstration and sampling of the fixed combination treatment of adapalene/benzoyl peroxide gel, medication adherence rates decreased from $86 \%$ after 1 week of treatment, to $36 \%$ in week 6 of treatment. ${ }^{23}$

The use of technology has the potential to play a major role in increased adherence. In an experiment where two different groups of adolescent acne patients were given a topical agent for acne treatment, the group given an automated weekly emailed survey was seen to have higher adherence than the group given no survey. ${ }^{24}$ This type of technological intervention may be more useful than other types of technologies such as automated text messaging reminders, which have been shown not to significantly increase adherence. ${ }^{25}$ The email survey technique encourages patients to act as active participants in their own treatment as opposed to automated text messaging reminders, where they play a more passive role. Surveys rather than reminders may also simulate a doctor's visit and enhance the "white coat compliance" effect, the phenomena where patients are more likely to listen when given direct instructions by a doctor. ${ }^{24}$ Survey-based technology also takes advantage of the long amounts of time adolescents spend on the computer and can be a cost-effective alternative to frequent follow-up visits in an attempt to increase adherence.

Education, specifically dynamic education, which consists of a more informative physician-patient interaction can also increase adherence. Acne patients with higher adherence 
Table 3 Summery of findings of literature search with hurdles to acne treatment adherence and interventions

\begin{tabular}{|c|c|c|c|c|}
\hline Study & Study type & Sample size & Hurdles to adherence & $\begin{array}{l}\text { Intervention to increase } \\
\text { adherence }\end{array}$ \\
\hline $\begin{array}{l}\text { Anderson et al } \\
(2015)\end{array}$ & $\begin{array}{l}\text { Cross-sectional, } \\
\text { observational }\end{array}$ & 143 & $\begin{array}{l}\text { Patients with busy lifestyles may forget to } \\
\text { apply medication or pick up prescription }\end{array}$ & \\
\hline Rueda $^{21}(2014)$ & $\begin{array}{l}\text { Randomized } \\
\text { controlled trial }\end{array}$ & 300 & $\begin{array}{l}\text { Patients may be confused about treatment } \\
\text { usage and stop using the medication }\end{array}$ & $\begin{array}{l}\text { Simplification of the therapeutic } \\
\text { regimen and considering patient } \\
\text { preference }\end{array}$ \\
\hline $\begin{array}{l}\text { Tan et } \mathrm{al}^{13} \\
(20 \mid 2)\end{array}$ & Review Article & & $\begin{array}{l}\text { Disagreement with the dermatologist's } \\
\text { recommendations due to information obtained } \\
\text { from nonmedical professionals, websites, } \\
\text { television advertisements, commercials, and } \\
\text { magazine articles }\end{array}$ & \\
\hline $\begin{array}{l}\text { Gorelick et a }\left.\right|^{14} \\
(2015)\end{array}$ & $\begin{array}{l}\text { Cross-sectional, } \\
\text { observational }\end{array}$ & 312 & $\begin{array}{l}\text { Skin condition may improve before obtaining } \\
\text { a prescription }\end{array}$ & \\
\hline $\begin{array}{l}\text { Gollnick } \\
(2015)\end{array}$ & Review Article & & $\begin{array}{l}\text { Topical retinoids have side effects such as } \\
\text { burning, irritation, and dryness }\end{array}$ & \\
\hline $\begin{array}{l}\text { Charakida et al }{ }^{17} \\
(2004)\end{array}$ & Review Article & & $\begin{array}{l}\text { Isotretinoin has been known to be } \\
\text { teratogenic, and causes cheilitis, dermatitis, } \\
\text { arthralgia, increased liver enzymes, cholesterol } \\
\text { levels, depression, and attempted suicide }\end{array}$ & \\
\hline $\begin{array}{l}\text { Renzi et al }{ }^{22} \\
(2002)\end{array}$ & $\begin{array}{l}\text { Cross-sectional, } \\
\text { observational }\end{array}$ & 396 & $\begin{array}{l}\text { Psychiatric comorbidities like depression cause } \\
\text { low adherence }\end{array}$ & \\
\hline $\begin{array}{l}\text { Sandoval et } \mathrm{al}^{23} \\
(20 \mid 4)\end{array}$ & $\begin{array}{l}\text { Randomized } \\
\text { controlled trial }\end{array}$ & 17 & $\begin{array}{l}\text { Adherence rates drop markedly over time } \\
\text { even after simplification of regimen }\end{array}$ & $\begin{array}{l}\text { Education via a physical } \\
\text { demonstration of use had I5\% } \\
\text { overall higher adherence rates }\end{array}$ \\
\hline $\begin{array}{l}\text { Yentzer et } \mathrm{al}^{24} \\
(20 \mathrm{II})\end{array}$ & $\begin{array}{l}\text { Randomized } \\
\text { controlled trial }\end{array}$ & 15 & & $\begin{array}{l}\text { Technology interventions, } \\
\text { specifically, automated email surveys } \\
\text { encouraging active participation } \\
\text { in treatment increase adherence. } \\
\text { Simulates "white coat compliance" }\end{array}$ \\
\hline $\begin{array}{l}\text { Boker et } \mathrm{al}^{25} \\
(2012)\end{array}$ & $\begin{array}{l}\text { Randomized } \\
\text { controlled trial }\end{array}$ & 40 & & $\begin{array}{l}\text { Text messaging reminders are } \\
\text { ineffective at increasing adherence }\end{array}$ \\
\hline $\begin{array}{l}\text { Miyachi et } \mathrm{al}^{26} \\
(20 \mathrm{II})\end{array}$ & $\begin{array}{l}\text { Cross-sectional } \\
\text { observational }\end{array}$ & 428 & & $\begin{array}{l}\text { Education and positive interaction } \\
\text { with the dermatologist increased } \\
\text { adherence }\end{array}$ \\
\hline $\begin{array}{l}\text { Feldman et al }{ }^{27} \\
(2007)\end{array}$ & $\begin{array}{l}\text { Randomized } \\
\text { controlled trial }\end{array}$ & 29 & & $\begin{array}{l}\text { Scheduling follow-up visits increases } \\
\text { adherence }\end{array}$ \\
\hline $\begin{array}{l}\text { Yentzer et al }{ }^{28} \\
(2011)\end{array}$ & $\begin{array}{l}\text { Randomized } \\
\text { controlled trial }\end{array}$ & 46 & & $\begin{array}{l}\text { Scheduling follow-up visits increases } \\
\text { adherence }\end{array}$ \\
\hline
\end{tabular}

reported that education and interaction with the dermatologist positively affected their behavior, while patients who were dissatisfied with their dermatologist interaction reported feeling unsure as to why they needed continuous treatment, what the expected results were, or how to prevent acne. ${ }^{26}$ Education could also involve using a more direct manner to teach the patient how to use the medication. Electronic adherence monitors revealed that mean adherence rates over a 6 -week period were $15 \%$ higher in the group given a physical demonstration of how to apply the medication versus the group given no demonstration. ${ }^{23}$ As the long length of some acne regimens directly play a role in nonadherence, physicians should highlight the fact that it takes some time for these regimens to show their effects. Reinforcement of this idea as part of the education process may lead to higher adherence. Acne medication adherence decreases over time; however, around the time of follow-up visits, medication adherence increases..$^{23,24,27}$ Scheduling follow-up visits is a potent intervention to increase adherence. ${ }^{28}$ Several of the hurdles that prevent adherence to medication stem from patients' concerns about things like adverse reactions to the medication, which can be further reinforced by media influences and their lack of knowledge about acne as a whole. ${ }^{9,17}$ Hurdles such as these can be addressed through dynamic education in combination with scheduling more follow-up visits. At follow-up visits, physicians can address concerns about side effects or usage and reassure patients on the importance of adherence if the patient feels as if there is 
a lack of progress. When frequent follow-up visits are not feasible, using substitutive technology methods that mimic the effects of visits should be considered.

Research on pathophysiologic pathways in acne may lead to new treatment modalities, but numerous acne treatments and various guidelines will be ineffective if they are not used by patients. ${ }^{29}$ A variety of interventions have been introduced that may help to improve acne treatment adherence, especially with recent technology achievements; however, establishment of novel solutions to increasing adherence is still needed.

\section{Conclusion}

- Acne medication adherence is poor and a major reason for treatment failure.

- This article examines the hurdles to adherence and solutions to these hurdles.

- Understanding hurdles to adherence and identifying the most effective solutions may help physicians to achieve better treatment outcomes.

\section{Acknowledgment}

Center for Dermatology Research was supported in part by an unrestricted educational grant from Galderma Laboratories, L.P.

\section{Disclosure}

Dr Feldman is a speaker for Janssen and Taro. He is a consultant and speaker for Galderma, Stiefel/GlaxoSmithKline, Abbott Labs, Leo Pharma Inc. Dr Feldman has received grants from Galderma, Janssen, Abbott Labs, Amgen, Stiefel/GlaxoSmithKline, Celgene, and Anacor. He is a consultant for Amgen, Baxter, Caremark, Gerson Lehrman Group, Guidepoint Global, Hanall Pharmaceutical Co Ltd, Kikaku, Lilly, Merck \& Co Inc, Merz Pharmaceuticals, Mylan, Novartis Pharmaceuticals, Pfizer Inc, Qurient, Suncare Research, and Xenoport. He is on an advisory board for Pfizer Inc. Dr Feldman is the founder and holds stock in Causa Research and holds stock and is majority owner in Medical Quality Enhancement Corporation. He receives Royalties from UpToDate and Xlibris. Sara Moradi Tuchayi, Tiffany Alexander, and Anish Nadkarni have no conflicts of interest to disclose.

\section{References}

1. Lee DJ, Van Dyke GS, Kim J. Update on pathogenesis and treatment of acne. Curr Opin Pediatr. 2003;15(4):405-410.

2. Timms RM. Moderate acne as a potential barrier to social relationships: myth or reality? Psychol Health Med. 2013;18(3):310-320.
3. Revol O, Milliez N, Gerard D. Psychological impact of acne on 21 st-century adolescents: decoding for better care. Br J Dermatol. 2015; 172(Suppl 1):52-58.

4. Tan X, Al-Dabagh A, Davis S, et al. Medication adherence, healthcare costs and utilization associated with acne drugs in Medicaid enrollees with acne vulgaris. Am J Clin Dermatol. 2013;14(3):243-251.

5. Moradi Tuchai S, Makrantonaki E, Ganceviciene R, Dessinioti C, Feldman SR, Zouboulis CC. Acne vulgaris. Nat Rev Dis Primers. 2015;1: 15029.

6. Iuga AO, McGuire MJ. Adherence and health care costs. Risk Manag Healthc Policy. 2014;7:35-44.

7. Anderson KL, Dothard EH, Huang KE, Feldman SR. Frequency of primary nonadherence to acne treatment. JAMA Dermatol. 2015; 151(6):623-626.

8. Baldwin HE. Tricks for improving compliance with acne therapy. Dermatol Ther. 2006;19(4):224-236.

9. Ghaderi R, Saadatjoo A, Ghaderi F. Evaluating of life quality in patients with acne vulgaris using generic and specific questionnaires. Dermatol Res Pract. 2013;2013:1-5.

10. Magin P, Heading G, Adams J, Pond D. Sex and the skin: a qualitative study of patients with acne, psoriasis and atopic eczema. Psychol Health Med. 2010;15(4):454-462.

11. White GM. Recent findings in the epidemiologic evidence, classification, and subtypes of acne vulgaris. J Am Acad Dermatol. 1998;39(2 Pt 3): S34-S37.

12. Dréno B, Thiboutot D, Gollnick H, et al. Large-scale worldwide observational study of adherence with acne therapy. Int $J$ Dermatol. 2010;49(4):448-456.

13. Tan X, Feldman SR, Chang J, Balkrishnan R. Topical drug delivery systems in dermatology: a review of patient adherence issues. Expert Opin Drug Deliv. 2012;9(10):1263-1271.

14. Gorelick J, Daniels SR, Kawata AK, et al. Acne-related quality of life among female adults of different races/ethnicities. J Dermatol Nurses Assoc. 2015;7(3):154-162.

15. Gollnick HP. From new findings in acne pathogenesis to new approaches in treatment. J Eur Acad Dermatol Venereol. 2015;29(Suppl 5):1-7.

16. Aydemir EH. Acne vulgaris. Turk Pediatri Ars. 2014;49(1):13-16.

17. Charakida A, Mouser PE, Chu AC. Safety and side effects of the acne drug, oral isotretinoin. Expert Opin Drug Saf. 2004;3(2):119-129.

18. Penna P, Meckfessel MH, Preston N. Fixed-dose combination gel of adapalene and benzoyl peroxide plus doxycycline $100 \mathrm{mg}$ versus oral isotretinoin for the treatment of severe acne: efficacy and cost analysis. Am Heal Drug Benefits. 2014;7(1):37-45.

19. Thiboutot D, Dréno B, Layton A. Acne counseling to improve adherence. Cutis. 2008;81(1):81-86.

20. Furue M, Onozuka D, Takeuchi S, et al. Poor adherence to oral and topical medication in 3096 dermatological patients as assessed by the Morisky medication adherence scale-8. Br J Dermatol. 2015;172(1):272-275.

21. Rueda MJ. Acne subject preference for pump over tube for dispensing fixed-dose combination adapalene $0.1 \%$-benzoyl peroxide $2.5 \%$ gel. Dermatol Ther (Heidelb). 2014;4(1):61-70.

22. Renzi C, Picardi A, Abeni D, et al. Association of dissatisfaction with care and psychiatric morbidity with poor treatment compliance. Arch Dermatol. 2002;138(3):337-342.

23. Sandoval LF, Semble A, Gustafson CJ, Huang KE, Levender MM, Feldman SR. Pilot randomized-control trial to assess the effect product sampling has on adherence using adapalene/benzoyl peroxide gel in acne patients. J Drugs Dermatol. 2014;13(2):135-140.

24. Yentzer BA, Wood AA, Sagransky MJ, et al. An Internet-based survey and improvement of acne treatment outcomes. Arch dermatol. 2011;147(10):1223-1224.

25. Boker A, Feetham HJ, Armstrong A, Purcell P, Jacobe H. Do automated text messages increase adherence to acne therapy? Results of a randomized, controlled trial. J Am Acad Dermatol. 2012;67(6):1136-1142.

26. Miyachi Y, Hayashi N, Furukawa F, et al. Acne management in Japan: study of patient adherence. Dermatology. 2011;223(2):174-181. 
27. Feldman SR, Camacho FT, Krejci-Manwaring J, Carroll CL, Balkrishnan R. Adherence to topical therapy increases around the time of office visits. J Am Acad Dermatol. 2007;57(1):81-83.

28. Yentzer BA, Gosnell AL, Clark AR, et al. A randomized controlled pilot study of strategies to increase adherence in teenagers with acne vulgaris. J Am Acad Dermatol. 2011;64(4):793-795.
29. Webster GF. Acne vulgaris. BMJ. 2002;325(7362):475-479.

Patient Preference and Adherence

Dovepress

\section{Publish your work in this journal}

Patient Preference and Adherence is an international, peer-reviewed, open access journal that focuses on the growing importance of patient preference and adherence throughout the therapeutic continuum. Patient satisfaction, acceptability, quality of life, compliance, persistence and their role in developing new therapeutic modalities and compounds to optimize clinical outcomes for existing disease states are major areas of interest for the journal. This journal has been accepted for indexing on PubMed Central. The manuscript management system is completely online and includes a very quick and fair peer-review system, which is all easy to use. Visit http://www. dovepress.com/testimonials.php to read real quotes from published authors.

Submit your manuscript here: http://www.dovepress.com/patient-preference-and-adherence-journal 